\title{
GAMBARAN RERATA KADAR KALSIUM DAN FOSFOR PADA PASIEN YANG MENJALANI HEMODIALISIS DI RS ANNA MEDIKA BEKASI
}

\author{
Nur Annisya ${ }^{1}$, Linda Armelia ${ }^{2}$ \\ ${ }^{1}$ Fakultas Kedokteran Universitas YARSI \\ ${ }^{2}$ Bagian Pendidikan Kedokteran Fakultas Kedokteran Universitas YARSI
}

\begin{abstract}
ABSTRAK
Penyakit Ginjal Kronik (PGK) adalah suatu proses patofisiologi dengan etiologi yang beragam, mengakibatkan penurunan fungsi ginjal yang progresif lambat. Hemodialisis digunakan sebagai terapi untuk mengganti fungsi ginjal yang memburuk. PGK memiliki mortalitas dan morbiditas tinggi, karena dapat menyebabkan berbagai macam komplikasi, salah satu komplikasi dari PGK yaitu ketikseimbangan pengaturan mineral khususnya kalsium dan fosfat. Jenis penelitian yang digunakan dalam penelitian ini adalah deskriptif kuantitatif dengan rancangan penelitian cross sectional. Populasi dalam penelitian ini adalah pasien PGK yang menjalani hemodialisis di RS Anna Medika Bekasi. Pemilihan sampel menggunakan teknik simple random sampling dengan syarat memenuhi kriteria inklusi. Pengambilan data sekunder (rekam medis). Dari 55 sampel didapatkan 32 pasien (58.2\%) dengan kategori hipokalsemia, 14 pasien (25.4\%) dengan kadar kalsium normal, 9 pasien (16.4\%) dengan kategori hiperkalsemia, 10 pasien (18.2\%) dengan kategori hipofosfatemia, 4 pasien (7.3\%) dengan kadar fosfor normal dan 41 pasien $(74.5 \%)$ dengan kategori. Dari 32 pasien $(58.2 \%)$ hipokalsemia dan $41(74.5 \%)$ hiperfosfatemia yang mengalami penurunan kalsium disertai peningkatan fosfor sebanyak 22 pasien (40\%). Pada penelitian ini didapatkan bahwa pasien lebih banyak mengalami hipokalsemia dan hiperfosfatemia. Kurang dari separuh pasien yang mengalami penurunan kalsium disertai peningkatan kadar fosfor.
\end{abstract}

Kata Kunci: Penyakit Ginjal Kronik; Hemodialisis; Kalsium; Fosfor

\begin{abstract}
Chronic Kidney Disease (CKD) is a pathophysiological process with a diverse etiology, resulting in slow progressive kidney function. Hemodialysis is used as a therapy to replace deteriorating renal function. PGK has high mortality and morbidity, because it can cause various complications, one of the complications of PGK is the regulation of mineral settings, especially calcium and phosphate. The type of research in this study is descriptive quantitative with cross sectional study design. The population in this study were PGK patients undergoing hemodialysis at Anna Medika Bekasi Hospital. Sample selection using simple random sampling technique with condition to fulfill inclusion criteria. Secondary data retrieval (medical record). From 55 samples were 32 patients (58.2\%) with hypocalcemia category, 14 patients (25.4\%) with normal calcium level, 9 patients (16.4\%) with hypercalcemia category, 10 patients $(18.2 \%)$ with hypophosphatemia category, 4 patients $(7.3 \%)$ with normal phosphorus levels and 41 patients $(74.5 \%)$ by category. Of 32 patients (58.2\%) hypocalcemia and 41 (74.5\%) hyperphosphatemia which decreased calcium along with a rise in phosphorus by 22 patients (40\%). In this study it was found that patients were more likely to have hypocalcemia and hyperphosphatemia. Less than half the patients had decreased levels of calcium along with elevated levels of phosphorus.
\end{abstract}

Keywords: Chronic kidney disease; hemodialysis; calcium; phosphorus 


\section{Pendahuluan}

Penyakit ginjal kronik (PGK) adalah suatu proses patofisiologi dengan etiologi yang beragam, mengakibatkan penurunan fungsi ginjal yang progresif, dan lambat. PGK umum nya berakhir dengan gagal ginjal yang memerlukan terapi pengganti ginjal (TPG) yang tetap, berupa dialisis atau transplantasi ginjal. ${ }^{1}$

Pasien PGK merupakan masalah kesehatan penting karena insidennya terus meningkat. Menurut United State Renal Data System (USRDS) di Amerika Serikat, prevalensi PGK meningkat $20-25 \%$ setiap tahunnya. Pada tahun 2010, tercatat sebanyak 116.946 penderita yang memulai TPG dari total penderita PGK yang mencapai 594.374 jiwa. ${ }^{2}$ Di Indonesia, penderita yang mengalami PGK dan menjalani terapi hemodialisis mengalami peningkatan. Berdasarkan survei yang dilakukan oleh Perhimpunan Nefrologi Indonesia terdapat 18 juta orang di Indonesia menderita $\mathrm{PGK}^{3}$ Menurut laporan IRR (2014), penggunaan dialiser menunjukkan adanya kenaikan dari tahun ke tahun dan sesuai dengan pertambahan pasien baru. ${ }^{4}$ Pada tahun 2012, tercatat sebanyak 140.710 pengguna dialiser, meningkat pada tahun 2013 sebanyak 156.395 dan meningkat lagi pada tahun 2014 sebanyak 234.546.

Pasien PGK memiliki mortalitas dan morbiditas yang cukup tinggi, karena dapat menyebabkan berbagai macam komplikasi yang serius. Salah satu komplikasi dari penyakit ginjal kronik yaitu ketidakseimbangan pengaturan mineral khususnya kalsium dan fosfat yang nantinya dapat menyebabkan Chronic Kidney Disease-Mineral Bone Disturbance atau yang biasa disebut Gangguan Mineral dan Tulang pada Penyakit Ginjal Kronik (GMT-PGK), biasanya dengan kadar $\mathrm{Ca}^{2+}$ rendah (hipokalsemia), $\mathrm{PO}_{4}{ }^{3-}$ tinggi dan hormon paratiroid yang tinggi.

Gagal ginjal merupakan penyebab tersering dari hiperfosfatemia. Tujuan dari penelitian ini untuk mengetahui gambaran rerata kadar kalsium dan fosfat pada pasien yang menjalani hemodialisis di RS Anna Medika Bekasi.

\section{Metode penelitian}

Studi ini merupakan studi deskriptif kolerasi dengan rancangan penelitian cross sectional. Sampel yang diambil adalah pasien PGK yang menjalani hemodialisis di RS Anna Medika Bekasi yang memenuhi kriteria inklusi (telah menjalani hemodialisis $>3$ bulan, dan pasin PGK yang melakukan pemeriksaan laboratorium kalsium dan fosfor) serta kriteria eksklusi (pasien gagal ginjal akut, dan yang belum dilakukan hemodialisis). Sampel diambil menggunakan teknik simple random sampling.

\section{Hasil}

Jumlah responden pada penelitian ini adalah 55 pasien PGK yang menjalani hemodialisis di RS Anna Medika Bekasi. Berdasarkan tabel 4.1 menunjukan karakteristik pasien berdasarkan usia, jenis kelamin, pekerjaan, dan riwayat penyakit. Sebagian besar pasien berusia 45-54 tahun (38.2\%) dan 55-64 tahun $(21.8 \%)$. Berdasarkan dari jenis kelamin terbanyak pada laki-laki (34.5\%). Berdasarkan dari jenis pekerjaan terbanyak pada kelompok wiraswasta (25.5\%) dan ibu rumah tangga (25.5\%). Berdasarkan dari riwayat penyakit terdahulu terbanyak pada kelompok hipertensi (50.9\%) dengan jenis kelamin laki-laki (67.8\%) dan diabetes melitus (36.4\%) dengan jenis kelamin laki-laki (60.0\%).

Tabel 4.2 menyajikan distribusi pasien PGK bersasarkan hasil pemeriksaan kalsium. Terdapat 32 pasien (58.2\%) yang memiliki kadar kalsium di bawah normal (hipokalsemia) dengan jenis kelamin laki-laki (59.4\%), 14 pasien (25.4\%) yang memiliki kadar kalsium normal dan 9 pasien (16.4\%) dengan peningkatan kadar kalsium (hiperkalsemia) dengan jenis kelamin laki-laki (66.7\%). 
Tabel 4.1. Data karakteristik pasien

\begin{tabular}{|c|c|c|}
\hline Variabel & $\begin{array}{c}\text { Jumlah } \\
\text { (n) }\end{array}$ & Persentase (\%) \\
\hline \multicolumn{3}{|l|}{ Usia (tahun) } \\
\hline $25-34$ & 6 & 10.9 \\
\hline $35-44$ & 9 & 16.4 \\
\hline $45-54$ & 21 & 38.2 \\
\hline $55-64$ & 12 & 21.8 \\
\hline$>65$ & 7 & 12.7 \\
\hline \multicolumn{3}{|l|}{ Jenis Kelamin } \\
\hline Laki-laki & 36 & 34.5 \\
\hline Perempuan & 19 & 65.5 \\
\hline \multicolumn{3}{|l|}{ Jenis Pekerjaan } \\
\hline Swasta & 10 & 18.2 \\
\hline Wiraswasta & 14 & 25.5 \\
\hline $\begin{array}{l}\text { PNS/TNI/ } \\
\text { Polri }\end{array}$ & 6 & 10.9 \\
\hline Pensiun & 11 & 20.0 \\
\hline $\begin{array}{l}\text { Ibu Rumah } \\
\text { Tangga }\end{array}$ & 14 & 25.5 \\
\hline \multicolumn{3}{|l|}{ Riwayat Penyakit } \\
\hline Hipertensi & 28 & 50.9 \\
\hline Laki-laki & 19 & 67.8 \\
\hline Perempuan & 9 & 32.2 \\
\hline Diabetes Melitus & 20 & 36.4 \\
\hline Laki-laki & 12 & 60.0 \\
\hline Perempuan & 8 & 40.0 \\
\hline Asam Urat & 4 & 7.3 \\
\hline Laki-laki & 3 & 75.0 \\
\hline Perempuan & 1 & 25.0 \\
\hline Lain-lain & 3 & 5.5 \\
\hline Total & 55 & 100 \\
\hline
\end{tabular}

Tabel 4.3 menyajikan distribusi pasien PGK berdasarkan hasil pemeriksaan fosfor. Terdapat 4 pasien $(7.3 \%)$ yang mengalami penurunan kadar fosfor (hipofosfatemia) dengan jenis kelamin laki-laki $(75.0 \%)$ yang sering terjadi, 10 pasien $(18.2 \%)$ yang memiliki kadar fosfor normal dan 41 pasien (74.5\%) dengan peningkatan kadar fosfor (hiperfosfatemia) dengan jenis kelamin laki-laki (65.9\%) yang sering terjadi.

Tabel 4.2. Distribusi pasien penyakit ginjal kronik berdasarkan hasil pemeriksaan kalsium.

\begin{tabular}{cccc}
\hline $\begin{array}{c}\text { Kadar } \\
\text { Kalsium }\end{array}$ & Kriteria & $\begin{array}{c}\text { Jumla } \\
\text { h }(\mathbf{n})\end{array}$ & $\begin{array}{c}\text { Persentase } \\
(\mathbf{\%})\end{array}$ \\
\hline $\begin{array}{c}8.8-10.8 \\
\mathrm{mg} / \mathrm{dl}\end{array}$ & Normal & 14 & 25.4 \\
\hline$<8.8$ & Hipokalsemia & 32 & 58.2 \\
$\mathrm{mg} / \mathrm{dl}$ & & & \\
& Laki-laki & 19 & 59.4 \\
& Perempuan & 13 & 40.6 \\
$>10.8$ & Hiperkalsemia & 9 & 16.4 \\
$\mathrm{mg} / \mathrm{dl}$ & & & \\
& Laki-laki & 6 & 66.7 \\
& Perempuan & 3 & 33.3 \\
Total & & 55 & 100 \\
& & & \\
\hline
\end{tabular}

Tabel 4.3. Distribusi pasien penyakit ginjal kronik berdasarkan hasil pemeriksaan fosfor

\begin{tabular}{llcc}
\hline $\begin{array}{l}\text { Kadar } \\
\text { Fosfor }\end{array}$ & Kriteria & $\begin{array}{c}\text { Jumlah } \\
\text { (n) }\end{array}$ & $\begin{array}{c}\text { Persentase } \\
\text { \% }\end{array}$ \\
\hline $2.5-4.5$ & Normal & 10 & 18.2 \\
$\mathrm{mg} / \mathrm{dl}$ & & & \\
$<2.5$ & Hipofosfatemia & 4 & 7.3 \\
$\mathrm{mg} / \mathrm{dl}$ & & & \\
& Laki-laki & 3 & 75.0 \\
& Perempuan & 1 & 25.0 \\
$>4.5$ & Hiperfosfatemia & 41 & 74.5 \\
$\mathrm{mg} / \mathrm{dl}$ & & & \\
& Laki-laki & 27 & 65.9 \\
& Perempuan & 14 & 34.1 \\
Total & & 55 & 100 \\
& & & \\
\hline
\end{tabular}

Berdasarkan tabel 4.4 dari 32 pasien hipokalsemia dan 41 pasien hiperfosfatemia yang mengalami penurunan kalsium disertai peningkatan fosfor yaitu sebanyak 22 pasien (40\%) dengan jenis kelamin laki-laki $(59.0 \%)$. 
Tabel 4.4. Distribusi pasien yang mengalami penurunan kalsium disertai peningkatan fosfor

\begin{tabular}{|c|c|c|}
\hline Kriteria & $\underset{\text { (n) }}{\text { Jumlah }}$ & Persentase \% \\
\hline $\begin{array}{l}\text { Mengalami } \\
\text { penurunan kalsium } \\
\text { disertai peningkatan } \\
\text { fosfor }\end{array}$ & 22 & 40.0 \\
\hline Laki-laki & 13 & 59.0 \\
\hline Perempuan & 9 & 41.0 \\
\hline $\begin{array}{l}\text { Tidak mengalami } \\
\text { penurunan kalsium } \\
\text { disertai peningkatan } \\
\text { fosfor }\end{array}$ & 33 & 60.0 \\
\hline Laki-laki & 23 & 69.7 \\
\hline Perempuan & 10 & 30.3 \\
\hline Total & 55 & 100 \\
\hline
\end{tabular}

\section{Pembahasan}

Hasil data yang diperoleh (Tabel 4.1) dapat dilihat bahwa kelompok usia 45-54 tahun (38.2\%) dan 55-64 tahun (21.8\%) merupakan kelompok usia terbanyak yang menderita penyakit ginjal kronik. Hasil ini tidak jauh berbeda dengan hasil penelitian yang dilakukan oleh Yudiantara (2016) yang menunjukkan bahwa usia terbanyak pasien ginjal kronik yaitu usia 30-59 tahun. ${ }^{5}$ Sesuai juga dengan data IRR 2016 bahwa terbanyak pada kelompok usia 5665 tahun. $^{4}$

Berdasarkan dari jenis kelamin (Tabel 4.1) penelitian ini menunjukan bahwa laki-laki lebih banyak mengalami penyakit ginjal kronik dibandingkan perempuan. Hasil ini sesuai dengan penelitian Pura dkk (2009) menunujukan perbandingan antara jumlah laki-laki dan perempuan yang mengalami penyakit ginjal kronik adalah $2: 1$. $^{6}$ Juga sesuai pada data IRR 2016 bahwa laki-laki lebih banyak mengalami PGK dibanding perempuan. Berdasarkan dari tabel 4.1 dapat dilihat bahwa hipertensi merupakan riwayat penyakit dahulu yang terbanyak pada pasien PGK. Hasil ini berbeda dengan data IRR 2016 yang menunjukan bahwa diabetes $(52 \%)$ merupakan penyebab terbanyak
PGK stadium 5 yang menjalani hemodialysis. ${ }^{4}$ Hal ini dimungkinkan keterbatasan jumlah sampel karena pemeriksaan laboratorium khusus nya kalsium dan fosfor tidak ditanggung oleh asuransi kesehatan.

Berdasarkan data yang diperoleh kadar kalsium pada pasien penyakit ginjal kronik yang berada di bawah nilai normal (hipokalsemia) sebanyak 32 pasien (58.2\%) dari 55 pasien (Tabel 4.2), hal ini sejalan dengan teori bahwa penyakit ginjal kronik adalah penyebab hipokalsemia yang paling sering terjadi, karena pada penyakit ginjal kronik akibat penurunan laju filtrasi glomerulus yang menyebabkan penurunan ekskresi inorganik fosfat dan menimbulkan retensi fosfat. ${ }^{7}$

Pasien penyakit ginjal kronik dengan kadar kalsium normal didapatkan 14 pasien (25.4\%) dari 55 pasien (Tabel 4.2) dan 9 pasien (16.4\%) dengan peningkatan kadar kalsium (hiperkalsemia). Dengan ditemukan responden yang mempunyai nilai kadar kalsium normal, dimungkinkan beberapa hal yang dapat mempengaruhi antara lain, masih ada nya respon dari tubulus ginjal untuk meningkatkan absorbsi kalsium atau adanya tubulus yang belum mengalami kerusakan. ${ }^{7}$ Ada beberapa faktor yang mempengaruhi kalsium pada pasien penyakit ginjal kronik seperti, makanan, obatobatan dan transfusi darah. Asupan kalsium yang dikonsumsi mempengaruhi absorbsi kalsium, penyerapan akan meningkat apabila kalsium yang dikonsumsi menurun. Vitamin D dalam bentuk aktif merangsang absorbsi kalsium melalui langkah-langkah kompleks. Makanan yang merupakan sumber kalsium seperti susu, keju, ikan, kacang-kacangan dan hasil kacangkacangan seperti tahu dan tempe. ${ }^{8}$

Pada Tabel 4.3, memperlihatkan pasien penyakit ginjal kronik di Rumah Sakit Anna Medika Bekasi paling banyak memiliki kadar fosfor yang tinggi, yaitu $>4.5 \mathrm{mg} / \mathrm{dL}$ dengan jumlah 41 pasien (74.9\%). Hal ini didukung oleh teori yang menyatakan bahwa kadar fosfor pasien penyakit ginjal kronik umumnya berkisar 
4.0-6.5 mg/dL. ${ }^{9}$ Pada keadaan ini dapat menyebabkan terjadinya hiperfosfatemia. Hiperfosfatemia pada penyakit ginjal kronik terjadi akibat kegagalan ginjal dalam mengekskresikan fosfat atau pelepasan fosfat dari ruang intraseluler. Ginjal merupakan organ ekskresi utama bagi fosfat, sehingga hampir tidak mungkin tidak terjadi hiperfosfatemia pada fungsi ginjal yang masih normal. ${ }^{7}$ Di Amerika Serikat, hiperfosfatemia jarang ditemukan pada pasien yang tidak terkena penyakit ginjal kronik atau pada populasi umum, namun tingkat hiperfosfatemia meningkat sebanyak $70 \%$ pada pasien penyakit ginjal kronik. ${ }^{10}$ Namun hasil tersebut berbeda dengan USRDS (United States Renal Data System) yang mengatakan bahwa prevalensi hiperfosfatemia masih $53.6 \%$, walaupun pengikat fosfat sudah diberikan pada

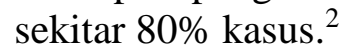

Berdasarkan tabel 4.4 bahwa pasien PGK di Rumah Sakit Anna Bekasi yang mengalami penurunan kalsium disertai peningkatan fosfor sebanyak 22 pasien (40\%) dan yang tidak mengalami penurunan kalsium disertai peningkatan fosfat sebanyak 33 pasien $(60 \%)$. Hal ini sejalan dengan teori bahwa pasien PGK, biasanya terdapat komplikasi kronik salah satunya adalah Gangguan Mineral dan Tulang pada Penyakit Ginjal Kronik (GMT-PGK), dimana kadar kalsium rendah (hipokalsemia), fosfat tinggi dan hormon paratiroid tinggi. Peningkatan hormon paratiroid bisa terjadi akibat retensi fosfat, yang menyebabkan turunnya kalsium terionisasi. ${ }^{11}$

Penelitian ini memiliki beberapa keterbatasan antara lain sedikitnya jumlah sampel yang diambil, sehingga tidak dapat mewakili seluruh populasi dan keterbatasan biaya, karena pemeriksaan laboratorium kalsium dan fosfor tidak ditunjang oleh asuransi kesehatan, sehingga tidak semua pasien melakukan pemeriksaan laboratorium tersebut. Saran untuk penelitian selanjutnya adalah dilakukan pengambilan sampel lebih banyak, sehingga dapat mewakili berbagai karakteristik populasi yang ada.

\section{Simpulan}

Berdasarkan hasil penelitian yang dilakukan di RS Anna Medika Bekasi dapat disimpulkan bahwa terjadi penurunan kadar kalsium dan penigkatan kadar fosfor pada sebagian besar pasien PGK yang menjalani hemodialsisis. Namun kurang dari separuh pasien yang mengalami penurunan kadar kalsium disertai peningkatan kadar fosfor.

\section{Saran}

Agar mengetahui dampak buruk yang ditimbulkan dari gangguan keseimbangan kalsium dan fosfor diharapkan dokter dapat melakukan penanganan untuk mengontrol keseimbangan cairan dan elektrolit pada pasien, sehingga tidak terjadi hipokalsemia dan hiperfosfatemia dan dapat terhindar dari komplikasi yang lebih lanjut. Bagi peneliti selanjutnya diharapkan dapat melakukan penelitian lebih lanjut dengan metode analitik sehingga bisa mengetahui adanya hubungan sebab akibat antara kedua variabel dan sampel yang lebih banyak, sehingga dapat mewakili seluruh populasi.

\section{Daftar Pustaka}

1. Suwitra, K. Peran gangguan fosfat dan kalsium pada morbiditas dan mortalitas penyakit ginjal kronik, dalam: Peranan stres oksidatif dan pengendalian resiko pada progresif Penyakit ginjal kronik serta Hipertensi. Jakarta: Nephrology and Hypertension Course. 2006.

2. United State Renal Data System, USRDS in Annual Data Report, Atlas of Chronic Kidney Disease in the United States. 2012; 1: 17-21.

3. Wiguno, P. and Suhardjono, A. End-Stage Renal Disease In Indonesia: Treatment Development. Ethnicity \& Disease, 2009; 1: 31-36.

4. Indonesia Renal Register. 2014. [cited 2016 November $\quad 2]$. Available from:http://www.indonesiarenalregistry.org/data/ indonesian\%20renal\%20registry\%202014.pdf. 
5. Yudiantara AR. Analaisis Perbandingan Kadar Kalsium Serum Penderita Gagal Ginjal Kronik Pre dan Post Hemodialisis Di Rumah Sakit Pertamina Bintang Amin Bandar Lampung. 2016.

6. Pura L., et al. Hubungan Filtrasi Glomerulus Dengan Status Nutrisi Pada Penderita Penyakit Ginjal Kronik Predialisis. 2009.

7. Guyton AC., et al. Textbook of Medical Physiology. Dalam: Rachman Yanuar L., et al (Editor Bahasa Indonesia). Buku Ajar

8. Fisiologi Kedokteran. Edisi 11. Jakarta: EGC. 2007.

9. Sudoyo., et al. Buku Ajar Ilmu penyakit Dalam. Jakarta: Departemen Ilmu Penyakit Dalam FKUI. 2009.

10. Wilson LM. Penyakit Ginjal Stadium Akhir: Sindrom Uremik. Dalam: Wilson LM (Editors). Pathophisiology. 2012.

11. Lederer A. Hyperphosphatemia. Medscape Reference: Drugs, Disease \& Procedures. 2015. Available from: http://emedicine.Medscape.com/article/2411 85-overview.

12. O'Callaghan C. Gagal Ginjal Kronik dan Renal Bone Disease. In: At a Glance Sistem Ginjal. Ed: $3^{\text {th }}$. Jakarta: Erlangga. 2009. 